\title{
Khoniates' Asia Minor: Earthly and Ultimate Causes of Decline
}

Niketas Khoniates' Khronikē Diēgēsis [hereafter Khronikēe] is the only surviving eyewitness Byzantine account of the Fourth Crusade, and the central historiographical source for the twelfth-century Empire. Born in c.1155-57 in the Phrygian city of Khonai, Khoniates was educated in Konstantinoupolis, began an administrative career which included both centralgovernment and provincial positions sometime before 1182, and reached the height of his career in the 1190s under the Angeloi, becoming logothetēs tōn sekretōn. ${ }^{1}$ A central figure until 1204, in the crusade's aftermath he first fled to Selymbria in Thrace, and thence to Nikaia in 1206, after a brief return to the City. Though Khoniates attempted to join the Laskarid court, he was unsuccessful, and died in poverty amongst other refugees living by Lake Askania in 1217.

The Fourth Crusade is therefore of paramount importance when approaching any aspect of the Khronike. A recent re-evaluation of the manuscript tradition has evidenced the narrative's incomplete revision and re-orientation, changing from a history of imperial reigns from Ioannes II Komnenos onwards, to a unified work seeking to explain the City's fall. ${ }^{2}$ This paper therefore will investigate Asia Minor's place within this explanation, asking how and why it was utilised. I will argue that Khoniates' Anatolian discussions introduce key vocabulary, and an important and idiosyncratic rhetorical tropos, lamentation. The repeated use of vocabulary, tropoi, or themes in different contexts in the narrative, integrates specifically Anatolian discussions with others elsewhere. This process of re-use and repetition will here be termed 'signification', whereby vocabulary, themes, or tropoi become 'signs', which allow Khoniates to underscore a point made in one discussion, and connect it with others simultaneously. This is the method by which Khoniates reminds the reader of previous criticisms, and connects them with the fall, creating a coherent and schematic explanation for decline.

All of Khoniates' criticisms are Kaiserkritik. Indeed, the same signification process is found in Khoniates' representation of Manuel, who is used to introduce the reader to traits which resurface in the emperors of the 1180-1204 period. These traits, like being in thrall to astrology, become more significant each time they resurface in different imperial personae. By the time the narrative reaches 1204, resonances between these personae have created the literary image of an imperial archetype represented as responsible for the fall. Paul Magdalino's conclusion was that Khoniates' account of Manuel's reign is not as trustworthy

\footnotetext{
${ }^{1}$ For an outline of Khoniates' work and life see: N. Khoniates, O City of Byzantium, Annals of Niketas Choniates, tr. H. Magoulias (Detroit, 1984), ix-xxviii

${ }^{2}$ For full discussion of the manuscript tradition: A. Simpson, 'Before and After 1204: The Versions of Niketas Khoniates' "Historia", Dumbarton Oaks Papers, Vol. 60 (2006), pp.189-221
} 
as Ioannes Kinnamos', but this is problematic. ${ }^{3}$ Narration requires authorial choice, so to seek trustworthiness is to miss the point, unless one seeks only basic facts. Rather than clouding his presentation of the reality of Manuel's reign, understanding that Khoniates' purpose is to explain 1204 allows better preparation in asking how and why he chose to emphasise particular character traits.

Here I will use Khoniates' Kaiserkritik to access his view on imperial policy towards Asia Minor. The narrative 'signs' relevant to Asia Minor will be contextualised by other sections of the work. Through this, it will be suggested that the narrative setting for imperial failure helps us to access where Khoniates thought real failures lay. Finally, I will propose that investigations of this kind allow us to see Khoniates' understanding of how historical process operates. This is through constant interplay between earthly agency and Divine Providence, which in the Khronike culminates with what Euthymios Tornikes named the "cosmic cataclysm' of the Fourth Crusade. ${ }^{4}$ Providence having this narrative role would not be unique; indeed, Holy Writ might be considered the guiding metanarrative of all Byzantine historiography. ${ }^{5}$ Yet Providence and imperial policy, as well as all human agency to some extent, are the intertwined motors of historical process. Human agency operates within circumstances constantly tailored by God, with His tailoring respondent to the manner of that action. The emperor's deeds, as those of the earthly vice-gerent of the Christian oikoumene, affected divine will towards the whole empire, so that to engage in Kaiserkritik is to seek a 'deeply religious explanation' for success or failure. ${ }^{6}$

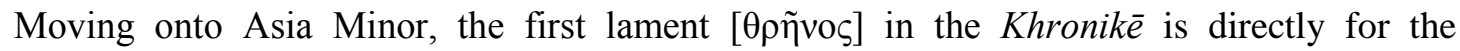
eleventh-century territorial losses. In Byzantine literature thrēnos normally signifies the Palaiologan-era and post-1453 political verse thrēnoi for lost cities, ${ }^{7}$ high-register prose laments are usually monodies. ${ }^{8}$ Khoniates' laments are reminiscent of these forms, but they also play a particular role in the narrative. Coming at the end of a single discussion, or, let us say, a single narrative unit, they draw the reader's attention to the importance of the preceding section by suddenly halting the text's chronological progression. There is drastic reduction of the narratorial voice's distance, suddenly moving from commentating 'outside' the narrative

\footnotetext{
${ }^{3}$ See: P. Magdalino, The Empire of Manuel I Komnenos, (Cambridge, 1993), pp.1-27.

${ }^{4}$ Euthymios Tornikes, 'Monody on the hypertimos of Neopatras', J. Darrouzes (ed.), 'Les discours d'Euthyme Tornikes (1200-1205)', REB 26 (1968), pp.82-3.

${ }^{5}$ I. Nilsson, \& E.C. Bourbouhakis, 'Byzantine Narrative: The Form of Storytelling in Byzantium', in L. James (ed.), A Companion to Byzantium, (Oxford, 2010), p.264.

${ }^{6}$ J. Harris, 'Distortion, Divine Providence and Genre in Nicetas Khoniates's Account of the Collapse of Byzantium 1180-1204', Journal of Medieval History, Vol. 26, (2000), p.25.

${ }^{7}$ For monody and thrēnoi see: A. Kazhdan, et al. (eds.) The Oxford Dictionary of Byzantium (Oxford, 1991), vol.2, p.1396, \& Oxford Dictionary, vol.3, pp.2081-2; for the Palaiologan-era thrēnoi see: M. Alexiou, Ritual Lament in the Greek Tradition (Rowman and Littlefield, 2002), pp.85-102.

${ }^{8}$ See: Oxford Dictionary, vol.2, pp.1396.
} 
inwards onto events for the reader [extra-diegetic], to 'inside' speaking outwards [intradiegetic], directly addressing God rather than the reader. Accompanying this is a radical change of narratorial mood, becoming emotive, biblical in style, and heavily utilising embedded, non-cited, scriptural references. The effect of this quick and tangible change for the scripturally-versed contemporary audience would be great, immediately alluding to the Book of Lamentations. Khoniates carefully controls his religious and Classical allusions, ${ }^{9}$ and the sheer scale of biblical references suggests that this tropos' religious colour is its most important feature.

This lament comes immediately after the description of Sultan Masud of Ikonion's division of his realm amongst his sons. ${ }^{10}$ It progresses from a series of rhetorical questions on how long calamity and loss will continue, to exhortations for God to intervene against the 'sons of Hagar'. Twelve scriptural quotes are incorporated into twenty one lines, making a dense mosaic of biblical references. The key words and central theme which will become 'signs' are

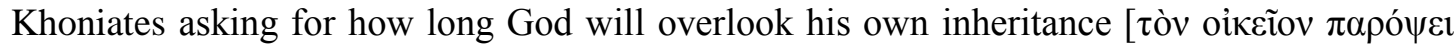

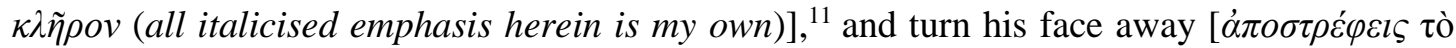

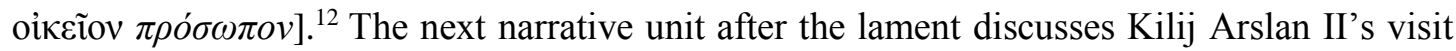
to Konstantinoupolis, with an apparently divine earthquake intervening so that the sultan cannot participate in a 'thoughtlessly conceived' triumph. ${ }^{13}$ This criticism indicates that the lament can be read as bemoaning both the eastern losses, and Manuel's policy towards the

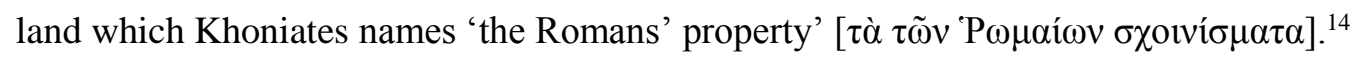

To contextualise this lament, elsewhere Khoniates bitterly recalls that this land had once been Roman. At the beginning of Book II of Manuel's reign in the section after the Second Crusade, Khoniates derides how Phrygia, Lykaonia and Pisidia are now enjoyed by barbarians because of the weak and 'stay-at-home' [oikovpía] approach of the Romans who had governed them. ${ }^{15}$ 'Homely' imagery suggests effeminacy, yet the words also indicate a real concern lest the provinces be neglected. By comparison, in the Book on Ioannes II Komnenos' reign, it says that he stayed on campaign against the Turks to defend his own

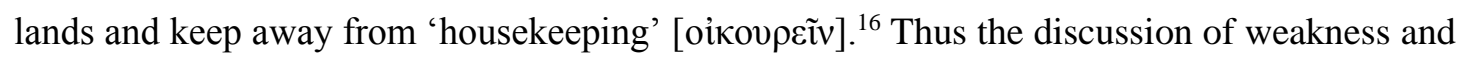

\footnotetext{
${ }^{9}$ S. Efthymiadis, 'Greek and Biblical Exempla in the Service of an Artful Writer', in Niketas Khoniates, p.116.

${ }^{10}$ Pagination and lineation refers to J. van Dieten's edition, see bibliography for full citation. 116.79117.4 .

${ }^{11}$ All biblical references refer to H.B. Swete's edition of the Greek Septuagint, see bibliography for full citation. Psalm 43.15; Deuteronomy 32.6.

${ }^{12}$ Psalm 12.2.

${ }^{13} 118.38-119.54$

${ }^{14} 117.8-9$.

15 72.81-5.

16 12.10-12.
} 
homeliness indicates that it is not only unmanliness, but also inaction and focus on the capital that lost these lands, and Ioannes' campaigning allows Khoniates to use the book on his reign to illustrate this point.

In fact, as opposed to his representation of Manuel introducing negative imperial traits, Khoniates casts Ioannes as the ideal emperor. ${ }^{17}$ Compared with later reigns, very few elaborate episodes for Ioannes are provided, which may reflect Khoniates' sources. Yet the textual length of Ioannes' reign is not the sole indicator of his importance in the narrative. Rather than his book being formed of a number of smaller narrative units, suffused with rhetorical tropoi, topoi, and paradeigmata, the entirety of Ioannes' reign forms one great paradeigma, the benchmark for Kaiserkritik. As with his other major figures, ${ }^{18}$ Khoniates augments Ioannes with Classical allusions to create a literary persona: embarking on his final

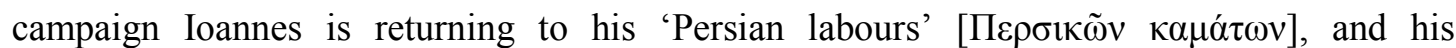
daughters cry like the Heliades, mythical daughters of Helios. ${ }^{19}$ This latter allusion may also be a denigration of Manuel, since it makes him Phaethon, the archetypal son unable to hold his father's reins. Additionally, Ioannes is one of the few people whom Khoniates never criticises,${ }^{20}$ is given the longest direct speech in the Khronike, ${ }^{21}$ and named the 'crown' of the Komnenoi, equalling some of the best Roman emperors and surpassing others. ${ }^{22}$ Indeed, the transition from Ioannes' well-ordered government, his empire-in-taxis, to the polyarchy of post-1204, can be said to be the key functional transformation of the entire narrative. ${ }^{23}$

It is crucial therefore that his eastern campaigning is constructed as the central feature of Ioannes' reign. $\mathrm{He}$ is the Homeric hero, with a silent and therefore apparently peaceful Konstantinoupolis, campaigning ceaselessly, especially in the East. Interestingly then, the entirety of Book VI is given to Myriokephalon, the longest campaign description in the Khronike, and the key aspect of Manuel's character in that book, rashness, is first seen in an episode during Ioannes' reign. ${ }^{24}$ Found in Kinnamos' history as well, and taking place in the Pontos during 1139-40, Manuel charges alone against the Turks, causing the Roman troops to fight harder. Whilst this factual framework is common to both historians, the implications are radically different. In Kinnamos, Manuel rallies the faltering army, with the author

\footnotetext{
${ }^{17}$ See particularly his final comments on his reign: 46.57-47.85.

${ }^{18}$ S. Efthymiadis, 'Greek and Biblical Exempla in the Service of an Artful Writer', in Niketas Khoniates, p.108.

19 37.73-82.

${ }^{20}$ S. Efthymiadis, 'Exempla' p.116.

21 42.20-46.40.

22 47.82-5.

${ }^{23}$ See for instance the interpretation of a deformed birth as presaging $\pi$ o $\lambda v \alpha \rho \chi i$, the mother of

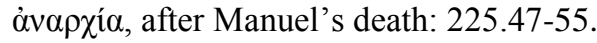

${ }^{24}$ 35.28-38; The Deeds of John and Manuel Comnenus by John Cinnamus, C.M. Brand (trans.), (Columbia, 1976), p.25-26.
} 
commenting how this exhibits his precocious courage, and that although Ioannes initially 'abused his rashness', 'internally admiration gripped him' ${ }^{25}$ In Khoniates, the army is not wavering, and he makes no direct comment. Instead, in almost complete inversion of Kinnamos, Ioannes publicly praises Manuel's action but later flogs him, commanding him not to personally engage with the enemy. It is clear that these accounts are connected, perhaps Khoniates knew Kinnamos', or they may both have used encomiastic accounts of the campaign. ${ }^{26}$ It may therefore be suggested that Khoniates has intentionally inverted the panegyric by inverting Ioannes' public and private reactions. Furthermore, by having his archetypal 'good' emperor give this lesson, Manuel's recklessness is established as a fundamentally 'bad' characteristic.

The Myriokephalon campaign then forms the narrative vehicle for fully exploring this trait. At the beginning of the book Khoniates contrasts Kilij Arslan II, who is methodical, exercises war through his generals, and never leads from the front, with Manuel, who possesses a noble nature, but is rash, and over-eager in war. ${ }^{27}$ The campaign then fails in part because Manuel allows his inexperienced gold-wearing relatives to convince him not to make peace, ${ }^{28}$ and afterwards is reckless in conducting the march. ${ }^{29}$ Thus, by Manuel's rashness as a sign of 'bad' emperorship, his Anatolian campaign is contrasted with those of Ioannes. However, Book VI does not end with Myriokephalon as an unredeemed disaster. Though Manuel apparently compared himself to Romanos IV Diogenes, ${ }^{30}$ in itself poignant, here the followup hostilities apparently go in the Romans' favour. The key factor is that Manuel now exercised the war through his generals, who win a victory which 'revived Roman prospects and diminished the Persians' insolences'. ${ }^{31}$ Moreover, the final action of the book is Manuel rushing to the aid of besieged Klaudioupolis, with Alexander-like disregard for comfort and desire for speed. ${ }^{32}$ Khoniates comments that acts like this caused Manuel to be more loved and admired than when he wore the golden trappings of imperial regalia, perhaps to be read as a 'homely' costume. Rather than condemn the Myriokephalon campaign then, Khoniates stresses Providence as the ultimate cause of failure. This is evident in a prophetic dream in which the Theotokos calls on the military saints, Georgios and Theodoros, to assist the emperor, but a voice responds that no-one can avert the coming evil. ${ }^{33}$ Indeed, the sultan

\footnotetext{
${ }^{25}$ Deeds, p.26

${ }^{26}$ Magdalino sees responding to official encomia as a feature of twelfth-century Kaiserkritik: P. Magdalino, 'Aspects of Twelfth-Century Kaiserkritik', in Speculum, vol.58, no.2 (April, 1983), p337.

27 175.39-176.48.

$28179.42-57$.

$29180.69-80$.

30191.27.

${ }^{31} 194.16-17$.

32 197.14-198.31.

33 190.83-191.8.
} 
offering the same peace terms after the battle as beforehand is ascribed to God's compassion lest his own inheritance [ Providence's role in territorial loss. ${ }^{34}$ The re-emergence of this sign, with Manuel's comparison of himself to Romanos IV, connects the loss at Myriokephalon with the original invasions of the 1070s, and Holy Writ is presented as the ultimate cause of both.

In describing the ensuing rout after Myriokephalon, Khoniates indicates the earthly causes for this divine wrath. ${ }^{35}$ Slowing the narrative's chronological speed, and allowing discursive time to expand so that he is followed through the confusion, Manuel is more 'present' in this section than any other. ${ }^{36}$ Two episodes here are visibly comments on specific policies, in both of which the same unnamed soldier berates Manuel. ${ }^{37}$ In the first, having narrowly avoided drinking blood, the soldier comments that Manuel has often drank that of his subjects 'by

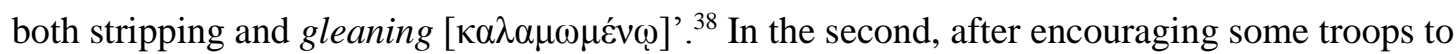
attack Turks looting money from the imperial treasury, the soldier retorts that this money should have been voluntarily given beforehand, thus emphasising the situation is of Manuel's making. Elsewhere there is criticism of Manuel's rapacious taxation, ${ }^{39}$ and these episodes indicate that divine wrath was in part drawn by this imperial failing. Manuel's previous actions mean that, despite being well-intentioned, the campaign is ordained to fail.

This general fiscal criticism could have been aimed at any or all of the Empire, and the fact that its narrative vehicle is an eastern campaign may be incidental. Yet if it is correlated with Khoniates' assessment of the new Anatolian theme Manuel establishes, Neokastra, I would argue that a special concern for Asia Minor's administration is evident. ${ }^{40}$ Khoniates describes the fortifying of the cities Chliara, Pergamon, and Atramyttion, and the building of fortresses to protect and revive local agriculture. Neokastra's significance is emphasised by it taking on Classical and Biblical allusion, with Manuel as Theseus, Athens' founder-king, and Neokastra as Eden. These are notable comparisons, particularly with Eden, the most poignant example of a perfect land lost. Moreover, Khoniates explicitly states that this was Manuel's greatest

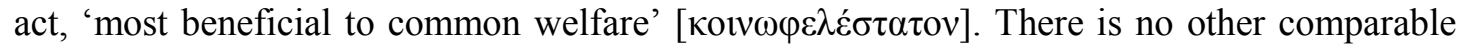
discussion of provincial building and administration in the Khronike, and at the very end of the passage it is highlighted how these fortresses contributed annual revenue to the imperial treasury. Neokastra's special emphasis means it is possible to suggest that fiscal-

\footnotetext{
${ }^{34} 188.19-20$.

35 184.9-187.18.

${ }^{36}$ S. Efthymiadis, 'The Writer', in Niketas Khoniates, p.40.

${ }^{37} 185.52-186.78$.

${ }^{38}$ This word is repeatedly used to describe rapacious taxes, and can be understood as another 'sign', see: $203.63, \& 556.87$.

$39204.79-89$.

40 150.35-56.
} 
administrative failure in Anatolia was the reason why Khoniates used Myriokephalon to express fiscal criticisms. By re-calling now the concept of God having abandoned 'his own inheritance', it is possible to begin to see interaction between human and divine agency, which appears to drive historical process in the Khronike.

The second lament further suggests these points, coming in book VII of Manuel's reign where Khoniates provides its final assessment. In form and theme it is a briefer version of the previous one and repeats the key vocabulary observed there. ${ }^{41}$ It also asks God how long he

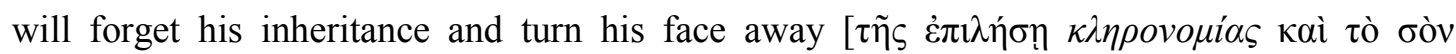
$\dot{\alpha} \pi \circ \sigma \tau \rho \varepsilon \dot{\varphi} \varphi \omega \nu \dot{\alpha} \varphi$ ' $\dot{\mu} \omega v \pi \rho o ́ \sigma \omega \pi o v]$, indeed, van Dieten attributes both instances to psalm 12.2. Furthermore, there are four scriptural references in these five lines, again a dense mosaic. The use of the same key vocabulary signifies that there is a connection between the two matters in discussion, and that for both a distinctly religious-coloured tropos is fitting, strongly indicating divine influence on events. Whilst heavily linked in language and form, the context of this lament is entirely different. It comes at the end of a discussion on the granting of paroikoi privileges in return for military service, in the section of the book which sums up Manuel's reign. Khoniates is clear in his opposition to this fiscal-military policy, stating that

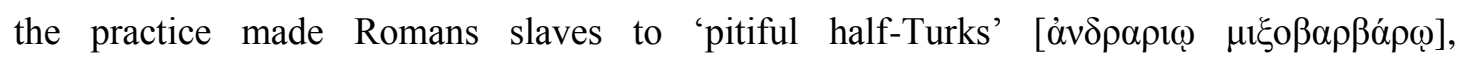
encouraged military indiscipline, and the ruin of the provinces by both Romans and foreigners. The re-emergence of these signs therefore links the original invasion of Anatolia with its perceived continued depredation by imperial policy.

Thematically, Turks and mixobarbaroi subjugating Romans in this lament and the previous one signifies the inversion of proper taxis, also evident in the Khronike's episode concerning Anna Komnene's attempted usurpation. ${ }^{42}$ Having confiscated Anna's possessions and planning to give them to Ioannes Axouch, the emperor comments: 'how taxis has been inverted against me! Kin have become my enemies and outsiders my friends! ${ }^{43}$ After Axouch has convinced him to return the property, Ioannes further notes how he would be 'unworthy

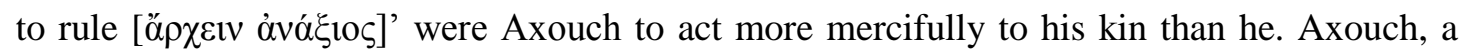
Romanised Turk, here illustrates how Roman rulers should behave. Thus, in having the Turks operate as even Kaloioannes' princely mirror, following the Classical topos, Khoniates' criticisms are crystallised as a barbarian provides the proper path.

Moreover, these critical contrasts can often be specifically linked with imperial policy in Asia Minor, as with Kilij Arslan and Manuel noted above. Another episode juxtaposes Kaykhusraw I with Alexios III Angelos. Alexios responds to a personal slight from the sultan

\footnotetext{
${ }^{41} 209.54-58$.

${ }^{42}$ A. Kaldellis, 'Paradox, Reversal and the Meaning of History', in Niketas Khoniates, p.79; 11.62-85.

${ }^{43} 11.82$.
} 
by imprisoning and seizing the property of both Roman and Turkish merchants from Ikonion, but rather than keep this in the imperial treasury 'as fitting' [ $\dot{\omega} \zeta \delta \varepsilon$ ćov], he dispersed it amongst courtiers. In direct contraposition, Kaykhusraw's reaction is to immediately raid Roman Asia Minor and take numerous prisoners. The unfavourable comparison is furthered by the sultan then conducting a meticulous survey of the captives, returning their goods, and settling them on fertile land. He additionally promised their return if peace-treaties with the empire are renewed, otherwise they would be free from tribute and tax-farmers for five years, and afterwards they would have an un-burdensome levy which would not be excessive 'as is

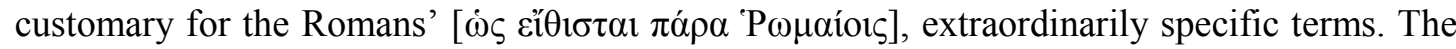
inversion is completed by other free Romans, encouraged by this treatment of their kinsmen, settling under Turkish rule. Alexios' only answer is a meaningless and abortive campaign.

This episode has the same fundamental feature as that of Axouch: the emperor's rash action over seized property is unfavourably compared with that of the Turk. However, here the latter proves more merciful, and therefore more worthy to rule Romans. To accentuate this point, Khoniates directly addresses the reader, saying that increasing lawlessness meant his generation's 'love froze', and people left the Hellenic cities and lived amongst the barbarians. ${ }^{44} \mathrm{He}$ moreover states that this was neither because of the failure of holy men, nor the waning of 'truths', but the regular tyrannies. This statement explicitly argues that the emperors themselves brought divine wrath, not religious fault.

These fiscal criticisms could have been made in narrative vehicles geographically elsewhere, the concurrent Asenid revolt in the Balkans for instance. Reasons must therefore be proposed for why Asia Minor is utilised. Whilst it may be because of the greater contrast with infidel barbarians rather than Christian ones, it might also reflect fears about cultural trends in Asia Minor. Though it is not fully understood, there was a composite Turko-Roman society in twelfth-century Anatolia, which produced the mixobarbaroi whom Khoniates noted as beneficiaries of paroikoi. Theodoros Balsamon gives tantalising hints of syncretic religious practices, mentioning certain circumcised Turks who had been baptised at birth by Orthodox priests. ${ }^{45}$ Classicising requirements and cultural conditioning means Khoniates maintains a strict division between Romans and barbarians. However, in recounting Ioannes' final campaign, he notes local Greek-speaking Christians who preferred to side with the Turks, notably stating: 'Thus custom, strengthened by time, is firmer than race and religion'. ${ }^{46}$ Understanding this concept, Khoniates' fears concerning imperial policy's inadequacy, in

\footnotetext{
44 495.47-496.53.

${ }^{45}$ C. Brand, 'The Turkish Element in Byzantium, Eleventh-Twelfth Centuries', in Dumbarton Oaks Papers, Vol.43 (1989), p.16.

46 37.85-38.12.
} 
comparison with that of the Turks, become focused. In an inversion of taxis, the Turks are more merciful towards the Roman 'kingroup' than the emperors, and thus, as Ioannes noted, the latter are no longer worthy to rule. Within the narrative the end result is the Romans losing land and resources more by default than outright conquest, with ineffective rulers doing little to reverse the trend.

As the narrative nears 1204 , the provinces are increasingly less present, with a restive Byzantion beginning to dominate, further suggesting the idea that the capital is at peace when absent from the text. The sack itself commences with an ordered account, detailing specific Latin crimes with little allusive or emotive language.$^{47}$ Efthymiadis proposed that the lack of biblical or Classical references in the actual description of the sack reflects Khoniates' personal and emotional experience of it, and that the section is unfinished. ${ }^{48}$ However, mirroring earlier instances of lamentation, there is here the stylistic juxtaposition between calm, extra-diegetic description of events, and subsequent, emotive, intra-diegetic lamentation, inundated with scriptural reference. Having 'exposed' the Latins for fraudulently claiming to be Christ's soldiers, the final part of the book is a lament for the City. Similar in form to the previous two instances discussed, there are fifty-seven scriptural references in 146 lines. Khoniates himself implies that this tropos indicates that he has reached a point of real

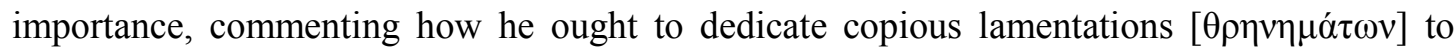
God, and refrain from continuing the sequence of his history. ${ }^{49}$

Yet unlike the previous laments, here Khoniates proposes an eventual resolution. Immediately prior to the beginning of the sack it appears that the Romans may prevail, but the chance loss of the Petria Gate negates this. Khoniates ascribes this to God even more explicitly than with Myriokephalon, saying that Konstantinoupolis' fall was necessary because all the Romans, both priest and people, had 'turned away from him'. ${ }^{50}$ Moreover, in the lament Khoniates illustrates how God both takes and gives through a series of rhetorical antitheses, elaborating the view that the conquest is part of God's plan to chastise the Romans, and that exile will not last forever. ${ }^{51}$ The same key vocabulary is also used, but in a novel manner. Khoniates writes:

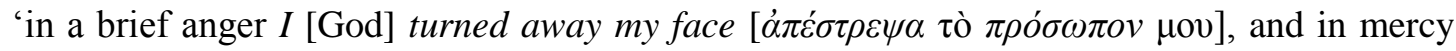
everlasting I will take pity on you'. ${ }^{52}$ The possibility of salvation is underlined by the final passage of the lament in which Khoniates exhorts the Romans to sing psalms, urging the Lord

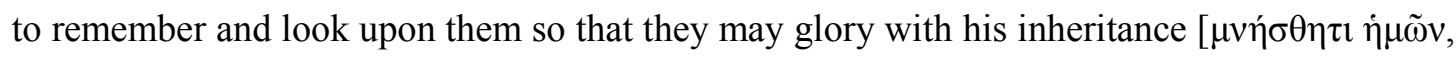

\footnotetext{
47 576.1-582.46.

${ }^{48}$ S. Efthymiadis, 'Exempla' p.118.

49 579.84-580.85.

50 569.9-10.

51 580.2-581.27.

$52578.41-42$.
} 


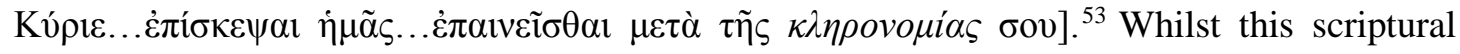
quotation has been attributed to psalm 105.4 by van Dieten, its vocabulary means it must also be connected with Lamentations 5.1-2, 'Remember Lord what has happened to us, look... Our

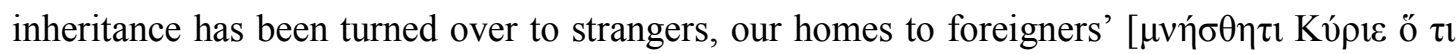

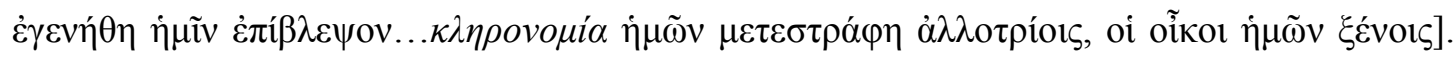
Khoniates has used the same vocabulary, or almost exact synonyms performing the same grammatical functions [ $\dot{\varepsilon} \pi \dot{i} \sigma \kappa \varepsilon \psi \alpha \mathrm{V} / \dot{\varepsilon} \pi \dot{i} \beta \lambda \varepsilon \psi o v]$, but has changed the emphasis so that now the 'inheritance' is firmly God's, to be returned at his volition. Thus, through using the same verbal and thematic tesserae from previous laments, Khoniates connects the loss of Konstantinoupolis to the initial losses in Anatolia, and the imperial policies which he believed allowed the situation there to deteriorate. The re-emergence of these signs indicates a chain of earthly and ultimate causes, showing constant interplay between imperial policy, and divine displeasure at the treatment of His 'own inheritance'.

The result is seen in the final coda to the Khronike,, 'The Events after the Conquest of Konstantinoupolis'. The functional transformation of the Khronike is complete: ataxia reigns, Khoniates reserves the imperial title for the Latins, Baldwin and Henry of Flanders, and Theodoros Laskaris by comparison is merely a scion of the 'three-headed monster of polyarchy constituted of the stupid' which engulfed the east. ${ }^{54}$ In a notable self-comparison, Khoniates bemoans how he has become Jeremiah, the traditional author of the biblical Lamentations, resentfully commenting that the Romans became a new Israel and Judah. ${ }^{55}$ Twice he also specifically attacks the Asian Romans for their internecine conflict, ${ }^{56}$ whilst the European Romans' rebelled against the Latins just in time to save Asia Minor from conquest. ${ }^{57}$ In recounting his own eventual journey to Nikaia, Khoniates introduces us to the final irony: the stay-at-home [oikovpótnৎ] ministers, ${ }^{58}$ who 'would not in any way enter the eastern lands, ${ }^{59}$ brought the Latins in as divine punishment, in the process being exiled to an uncaring east to be looked down on as foreigners by the inhabitants. ${ }^{60}$

Khoniates' bitter account of the Roman world's break-up shows clearly that 1204 was truly the aforementioned 'cosmic cataclysm'. My task was to show how and why Asia Minor was integrated with Khoniates' general explanation for decline. This explanation is 'conventionally religious', emphasising imperial responsibility for divine favour, and Holy

\footnotetext{
53580.85 .

${ }^{54} 625.44-46$.

55 625.35-6.

56 625.24-27; 625.39-42.

${ }^{57} 613.73-76$.

58586.67 .

${ }^{59} 645.71$.

${ }^{60}$ 645.80-83.
} 
Writ's just certainty. ${ }^{61}$ Yet Khoniates does not prioritise 'moral' issues like astrology. Rather, his Kaiserkritik attacks actual policies, and uses specific literary devices to connect these criticisms with each other, and the fall. Through the signification of certain themes, vocabulary, and rhetorical tropoi, Khoniates connects Ioannes' campaigning, Manuel's fiscal policies, and Alexios III's general weakness, thereby providing both specific and paradigmatic examples of success and failure. Moreover, the boundaries within which success and failure operate are divinely ordained. So with Myriokephalon Manuel's punitive fiscal policies mean that it is predestined to fail, despite Khoniates not criticising the campaign in principle. It therefore seems that there was particular fiscal mismanagement in Anatolia, particularly excessive and arbitrary taxation, and as a result of this an expansion of Turkish power. Moreover, Khoniates indicates that the emperors were less than assertive in the defence of their lands, characterising particularly the Angeloi as ineffective and weak. Thus, within the narrative, Asia Minor's mismanagement forms a paradeigma for wider imperial failure, foreshadowing the City's fall. Yet these are one man's criticisms, formed over a long period both at the heart of government and in subsequent destitute exile. Assessing their implications must rest on more work, viewing the Khronike within eleventh- and twelfthcentury political-rhetorical discourse, assessing literary attitudes towards the Turks and Asia Minor in general, and, most importantly, further analysing this pivotal text from as many approaches as possible.

${ }^{61}$ Magdalino, Empire, p.14. 


\section{Bibliography}

\section{Printed Primary Sources}

N. Khoniates, Nicatae Choniatae Historia, ed. J. van Dieten, (Bonn, 1975).

N. Khoniates, O City of Byzantium, Annals of Niketas Choniatēs, tr. H. Magoulias (Detroit, 1984)

I. Kinnamos, The Deeds of John and Manuel Comnenus by John Cinnamus, trans. C.M. Brand, (Columbia, 1976).

The Old Testament in Greek: according to the Septuagint, H.B. Swete, $4^{\text {th }}$ edn (3 vols., Cambridge, 1909-1912).

E. Tornikes, 'Monody on the hypertimos of Neopatras', ed. J. Darrouzes, 'Les discours d'Euthyme Tornikes (1200-1205)', Revue des études byzantines, 26 (1968), pp.82-83.

\section{Secondary Literature}

Alexiou, M., Ritual Lament in the Greek Tradition (Rowman and Littlefield, Lanham 2002).

Brand, C., 'The Turkish Element in Byzantium, Eleventh-Twelfth Centuries', in Dumbarton Oaks Papers, vol.43 (1989), pp.1-25.

Efthymiadis, S., 'Greek and Biblical Exempla in the Service of an Artful Writer', in Simpson, A., \& S. Efthymiadis (eds.), Niketas Khoniates: Historian and Writer (Pomme d'Or, Geneva 2009), pp.101-120.

Efthymiadis, S., 'The Writer', in Simpson, A., \& S. Efthymiadis (eds.), Niketas Khoniates: Historian and Writer (Pomme d'Or, Geneva 2009), pp.35-58.

Harris, J., 'Distortion, Divine Providence and Genre in Nicetas Khoniates's Account of the Collapse of Byzantium 1180-1204', Journal of Medieval History, Vol. 26 (2000), pp.19-31

Kaldellis, A., 'Paradox, Reversal and the Meaning of History', in Simpson, A., \& S. Efthymiadis (eds.), Niketas Khoniates: Historian and Writer (Pomme d'Or, Geneva 2009), pp.75-100.

Kazhdan, A., et al. (eds.), The Oxford Dictionary of Byzantium (3 vols., Oxford, 1991).

Magdalino, P., The Empire of Manuel I Komnenos (Cambridge, 1993). 
Magdalino, P., 'Aspects of Twelfth-Century Kaiserkritik', in Speculum, vol.58, no.2 (April, 1983), pp.326-46.

Nilsson, I., \& E.C. Bourbouhakis, 'Byzantine Narrative: The Form of Story-telling in Byzantium', in L. James (ed.), A Companion to Byzantium (Blackwell's, Oxford 2010), pp.263-274.

Simpson, A., 'Before and After 1204: The Versions of Niketas Khoniates' "Historia", in Dumbarton Oaks Papers, vol.60 (2006), pp.118-221.

Simpson, A., 'Niketas Khoniates: The Historian', in Simpson, A., \& S. Efthymiadis (eds.), Niketas Khoniates: Historian and Writer (Pomme d'Or, Geneva 2009) pp.13-34. 